Volume 5

Issue 1 Humans Being: People, Places,

Perspectives and Processes

Article 24

2011

\title{
Occupational Crowding by Race in the Pacific \\ Northwest: A Comparative Study of Portland, Oregon and Seattle, Washington
}

Moriah Willow

Portland State University

Follow this and additional works at: https://pdxscholar.library.pdx.edu/mcnair

Let us know how access to this document benefits you.

\section{Recommended Citation}

Willow, Moriah (2011) "Occupational Crowding by Race in the Pacific Northwest: A Comparative Study of Portland, Oregon and Seattle, Washington," PSU McNair Scholars Online Journal: Vol. 5: Iss. 1, Article 24. https://doi.org/10.15760/mcnair.2011.310

This open access Article is distributed under the terms of the Creative Commons Attribution-NonCommercialShareAlike 4.0 International License (CC BY-NC-SA 4.0). All documents in PDXScholar should meet accessibility standards. If we can make this document more accessible to you, contact our team. 
Portland State University McNair Research Journal 2011

Occupational Crowding by Race in the Pacific Northwest: A Comparative Study of Portland, Oregon and Seattle, Washington

by

Moriah Willow

Faculty Mentor:

Karen J. Gibson

Citation: Willow, Moriah. Occupational crowding by race in the Pacific Northwest: A comparative study of Portland, Oregon and Seattle, Washington. Portland State University McNair Scholars Online Journal, Vol. 5, 2011: pages [308-342] 
Occupational Crowding by Race in the Pacific Northwest: A Comparative Study of Portland, Oregon and Seattle, Washington

September 30, 2010

Moriah Willow

McNair Fellow

Faculty Mentor: Karen J. Gibson, PhD

Portland State University

moriah.willow@gmail.com 


\begin{abstract}
In a classic study of racial segregation within the US labor force entitled "The Effect on White Incomes of Discrimination in Employment.” economist Barbara Bergmann, found that Black men were more concentrated in laborer and low skill occupations than their white counterparts and virtually excluded from high status occupations (Bergmann. 1971). In a follow up study "Revisiting Occupational Crowding in the United States: A Preliminary Study " Gibson, Darity and Myers found similarly high levels of occupational crowding in some blue-collar occupations, high levels of gender segregation in the occupational distribution and under-representation of Blacks in high status/wage occupations. Gibson, et al used regional data from the 1990 US Census to analyze occupational crowding among 59 occupations in Detroit, Michigan and Pittsburgh, Pennsylvania. The regional focus captures many of the localized aspects of each region's labor market that are obscured with national level data. This study builds upon the previous two by utilizing the same crowding index and similar regional data to evaluate Black occupational patterns in Portland, Oregon and the Seattle, Washington in 2000. This study finds that occupational segregation persists in the new millennium, as there were similarly high levels of occupational in some blue collar occupations, high degrees of occupational sex segregation and underrepresentation of Blacks in high wage/status occupations in both Portland and Seattle. However, Black men and women in Seattle had significantly higher levels of representation in healthcare and clerical occupations. Black men in Portland were slightly better represented in skilled crafts occupations than Black men in Seattle.
\end{abstract}




\section{Introduction}

Although African Americans have made considerable economic gains since the Civil Rights Movement of the 1960’s, racial economic inequality has persisted and has in some ways worsened. In the 1970's, economist Barbara Bergmann, interested in the underlying dynamics which perpetuate racial inequality, focused on employment discrimination as a leading factor. In a well known study entitled "The Effect on White Incomes of Discrimination in Employment”.(1971), Bergmann examined US Census data from 1960 to investigate the extent to which African American men were limited to restricted set of occupations. Bergman (p. 295) argued that racial discrimination in employment had led to a "crowding effect”, whereby Black men were segregated into a small number of low status occupation which resulted in lower earnings than similarly skilled White men. Gibson, Darity and Myers (1998) examined occupational crowding in Wayne County (Detroit), and Allegheny County (Pittsburgh) using an index similar to Bergmann's (that controlled for the educational level of the worker). This study found similar levels of crowding in 1990, among some low wage blue collar occupations as well as Black underrepresentation in high paying managerial/specialty occupations. One of the study's more notable conclusions was the degree to which racial occupational patterns in blue collar jobs had persisted between 1960 and 1990. In the current study, like Gibson, et al, I will utilize 5\% Public Use Micro-data Samples (PUMS) from the US Census Bureau to analyze the extent to which African Americans are crowded into certain occupations and out of others. This data set contains detailed information regarding household and personal characteristics for individuals based on geographic area. This study utilizes regional rather than county level data from the 2000 Census for Portland, Oregon and Seattle, Washington Metropolitan Statistical Areas (MSA's), which in this case, represent combinations of multiple counties. The occupations 
analyzed in the current study are very similar* to the set used by Gibson, Darity and Myers (1998) and the crowding index is identical. This study will attempt two primary tasks:

1.) To compare occupational patterns by race in Portland, Oregon and Seattle, Washington

2.) To compare and contrast the results of this analysis to those found in "The Effect on White Incomes of Discrimination in Employment.”(Bergman 1971.). And, “Revisiting Occupational Crowding in the United States: A Preliminary Study “(Gibson, Darity and Myer 1998).

This article is broken into five sections. In the next section I describe why Portland and Seattle provide an interesting theoretical case study and discuss the origins of the African American communities of the Pacific Northwest, highlighting economic and historical contrasts which affect the differential occupational opportunities available to African Americans in both cities. In section three I discuss the persistence of racial economic inequality in the US, review past scholarship on occupational segregation by race and gender and discuss African American access to desirable occupations. Section four consists of an overview of the study's methodology and discussion of similar past studies. In section five I present a summary of my findings, compare my findings to past research and offer my conclusions.

\section{Why Seattle and Portland?}

The primary reason the Seattle, Washington and Portland, Oregon MSA's were selected is because both cities reside in the relatively racially homogenous Pacific Northwest and posses small Black populations, unlike Pittsburgh and Detroit, which posses much larger Black populations. Numerous studies have linked Black population size with Black to Black-White inequality in the United States across a broad spectrum of labor market outcomes (Seymore, Hoyt and Scott 1984; Beggs 1995, Cohen 2001, Huffman and Cohen 2004). The “competition” 
or "visibility-discrimination" hypothesis attributes this positive association between racial concentration and inequality to a White response to the threat posed by larger minority group size (Burr, Galle and Fossett 1991, Beggs, Villemez and Arnold 1997. Huffman and Cohen 2004). The Black populations in Portland and Seattle MSA's are small (2.6\% and 4.3\% respectively), which would suggest that racial employment discrimination would be less pronounced than in Pittsburgh and Detroit. However, as it relates to occupational crowding and segregation, this study corroborates Gibson et al, finding that city-city occupational patterns, in terms of gender and racial representation are unique and deeply rooted in history.

\section{The African American Communities of Seattle, Washington and Portland, Oregon}

The African American communities of Seattle and Portland arose primarily during 1940's as Southern Blacks migrated and were recruited from across the United States to work in wartime industries. Between 1940 and 1950 Portland's African American community expanded by close to 400 percent, from 1,931 to 9,529 (Taylor 1981). Similarly, Seattle's Black population grew by over 300 percent, from 3,789 to 15,666.

In Seattle, home of the Boeing Company, Black workers found employment both in aircraft and shipbuilding industries, while Blacks migrants to Portland found employment primarily in the Kaiser shipyards owned by the powerful California industrialist Henry J. Kaiser. Blacks in Seattle's were openly welcomed into shipbuilding industries and to a lesser degree within aircraft industries so that by the end of WWII the outlook for African Americans in Seattle was promising, strengthened by the diversity in employment opportunities.

In Portland, Black and White wartime workers from the South were met with open hostility and a severe shortage of housing greatly exacerbated racial tensions. In addition, Black workers in 
Portland also experienced severe discrimination from most local labor unions, particularly the Boilermakers Union. However, there were a few exceptions. For example, the Building Worker's Union (Local 299) had 2,000 Black members out of about 5,500 total members and the Electrical Workers Union had nearly 1,000 Black members out of a total of 8,000 (City Club of Portland 1945). Regardless, thousands of African American workers left the Portland area when ship production was curtailed at the end of the war. Some returned to the South, while others sought employment in Seattle or in California. By 1947 the number of Blacks in the PortlandVancouver area had dwindled from a high of 21,000 in 1945 to approximately 12,000 persons (Taylor 1981). Of the 4,500 blacks in the Portland labor force in 1947, only about one-third were employed.

Five decades later, African Americans in Portland continued to face greater barriers to economic opportunity as compared with their counterparts in Seattle. While an accurate economic comparison between African Americans in Portland and Seattle is difficult because wages are higher in Seattle and unemployment is far lower, a comparison of educational attainment is strongly illustrative of the achievement gap between the two Black communities. Just 21\% of Portland Blacks had completed two years of college or more, while 30.6\% had in Seattle. 22.7\% of Blacks had earned a four year college degree or professional/graduate degree in Seattle compared to $15.7 \%$ of Blacks in Portland (PUMS 2000). This disparity may come as a result of number of factors. Because Seattle is a larger city with more job opportunities there may be more incentive for African Americans to pursue secondary education. In addition, higher wages and lower levels of unemployment in Seattle may be a draw to ambitious Blacks in Portland and elsewhere. 


\section{The Persistence of Racial Economic Inequality}

In 1970, Black poverty levels in Seattle, Portland and the nation were twice White poverty levels, Black unemployment levels were close to double White unemployment and Black percapita income was half White per capita income. Thirty years later in 2000, Black unemployment

had worsened considerably, Black poverty levels were nearly triple White poverty levels and Black per capita income was less than $60 \%$ of White per capita income. These trends fly in the face of the American meta-narrative of continuous progress towards racial equality in the postCivil Rights Era. However, a large body of empirical research reveals the continued economic marginalization of African Americans in the US labor force whether measured in terms of labor market discrimination in hiring (Darity and Mason 1998; Pager 2003), promotion (Muame Jr. 1999), wage inequality (Cohen and Huffman 2004. Dozier, 2007; Pettit and Ewert 2009) or labor force participation (Brown 1997; Holzer, Offner and Sorensen 2004).

\section{Occupational Segregation and Crowding by Race and Gender}

Race and gender segregation in the US workforce is an extremely important issue because it adversely affects the economic status of both minorities and women. Job segregation negatively affects the relative wages of women (B. F. Reskin 1988. Cohen and Huffman 2002 and 2003), and African Americans (Cohen and Huffman 2004). Black women, who carry the burden of both gender and racial discrimination, experience a 3\% wage tax as compared to similarly skilled White women in the same occupational category (Kim 2002). An additional consequence of occupational segregation is that it can play a strong role in perpetuating and reinforcing race and gender stereotypes that can limit future educational and economic opportunities and, in turn, limit future occupational opportunities. 
Scholarship on the racial desegregation of the US workforce indicates that most sustained and rapid progress was made in the initial period following the Civil Rights Act, when many employers experimented with new human resource practices and Equal Opportunity Compliance Standards were unclear (Tomoskovic-Devey and Zimmer 2007). However, when political pressure declined markedly in 1980 during the Reagan Administration, progress towards racial desegregation in the private sector all but stopped (Tomoskovic-Devey and Zimmer 2006; King 1992). In addition, research shows that occupational race segregation varies regionally and interregionally, with the American South being historically more racially segregated than the rest of the nation (King 1992; Fosset, Galle and Kelly 1986; Burr, Galle and Fossett 1991; Fosset and Swicegood 1982). Unfortunately, the researcher was not able to find any regionally focused studies which dealt specifically with occupational segregation in the Pacific Northwest and hope that this study may help fill that research gap.

\section{African American Access to Desirable Occupations}

In an often cited article entitled "Discrimination and Desegregation: Equal Opportunity Progress in U.S. Private Sector Workplaces Since the Civil Rights Act" published in 2007, noted sociologists Kevin Steinback and Donald Tomaskovic-Devey examined patterns of racial representation over time in three desirable occupational categories: craft production, managerial and professional occupations. Within craft production occupations, which continue to be highly gender segregated, they found that African American men had made considerable progress in the initial post-Civil Rights Act period, followed by slower gains during the 1970's and a slight decline after 1985. Within managerial occupations, they found that Black men made no progress in the initial post-Civil Rights Act period, but did make slow progress during the 1970's. In the 1980’s desegregation stalled, but progress began anew across the 1990's. Black women's 
progression into managerial positions followed a similar pattern, but Black men continue to be more advantaged (Muame 1999; Steinback and Tomaskovic-Devey 2007 ). However, African American men and women were found to be considerably underrepresented in private sector managerial positions, with some regional and inter-regional variation (Huffman and Cohen 2007). In the 1960’s, Black men and women, with some exceptions, were all but absent from professional and specialty occupations but by 2002, Black men and women had gone from $90 \%$ underrepresentation to $63 \%$ underrepresentation and 52\% respectively.

However, Black women hold a small advantage over Black men in professional occupations which can be partially attributable to the gender differences in occupational opportunity. Men have access to relatively high paying jobs in skilled crafts, security oriented occupations and construction related jobs, which require far less formal education than similarly rewarded female gender-typed jobs. Many of these female gender typed occupational niches are found within the public sector, where Black women are thought to face lower levels of discrimination. Thus, the impetus to strive for advanced levels of education may be stronger for Black women than Black men.

\section{Bergmann in 1960 and Gibson, Darity and Myers in 1990}

In “The Effect on White Incomes of Discrimination in Employment” (Bergmann 1971), Barbara Bergmann used US Census Data from 1960 to identify which occupations were characterized by underrepresentation of Blacks. Controlling for education, Bergmann developed a representation scheme that deduced the appropriate number of Blacks in any occupation based upon the portion of the Black male population who would be eligible for any given occupation based upon educational credentials. However, Bergmann was only concerned with occupations which required low levels of education. In "Revisiting Occupational Crowding in the United States: A 
Preliminary Study “(1998), 59 occupations “representing a broad cross section of jobs” in terms of skill and educational requirements were analyzed using 1990 5\% PUMS data for two counties: Wayne County in (Detroit, Michigan) and Allegheny County in (Pittsburgh, Pennsylvania).

The study found that within blue-collar and service employment, Black women were underrepresented in both craft and operative occupations and concentrated in low-skill service occupations. Black men were underrepresented in the craft occupations and concentrated in lowskill operative, laborer, and service occupations. Within white-collar employment, both Black men and women were largely excluded from high-skill private sector managerial occupations. However, Black representation in public sector managerial and private sector professional occupations was found to be better in Detroit than Pittsburgh because of the in-roads Detroit Blacks had been able to make in the city's institutions (schools, police, city government, etc) in the wake of white flight following deindustrialization. This case study provides a clear example the localization of occupational segregation on a city-to-city basis and the centrality of geographically specific historical context.

\section{The Bergmann Crowding Index}

The Bergmann crowding index is a useful measure of occupational inequality because it can signal the degree to which African Americans are numerically represented in occupations primarily because of an inadequate number of Blacks with appropriate level of educational attainment for the occupation or because of an artificial or discriminatory barrier to entry.

The crowding index is computed by calculating the ratio of the share of Black men or women in each occupation to the share of Black men or women in the population with the appropriate educational level (educational levels between the 25th and 90th percentiles for each occupation). 
According to the index, blacks are considered to be overrepresented in those occupations with crowding ratios more than $10 \%$ above unity, underrepresented in those occupations with crowding ratios more than $10 \%$ below unity, and evenly represented in those occupations with crowding ratios within $10 \%$ of unity.

For example, the educational attainment level for Administrators in education and related fields in the Portland MSA ranges from a graduate degree or $5+$ years of college education $\left(90^{\text {th }}\right.$ Percentile) to an Associate's degree or two years of college education ( $25^{\text {th }}$ Percentile). Since the Black male share of the occupation is $1.3 \%$ and the proportion of the Black male population with the appropriate level of education attainment for the occupation, out of the entire population, is $1.43 \%$, the crowding ratio is $90.91 \%$. This means that Black men are very close to proportionately represented in this occupation. This case of proportionate representation is very rare. In fact, of the eleven managerial occupations analyzed, Black men in Portland were significantly underrepresented in seven.

\section{Comparing Seattle and Portland}

The following is a summary overview of the findings on Seattle and Portland. The crowding indices for all occupations can be found in Appendix 2. This study finds Black men to be extremely underrepresented in the heavily unionized skilled craft occupations in both cities. Black men and women were also found to be underrepresented in private sector managerial, specialty and professional occupations but better represented in public sector managerial occupations in both Seattle and Portland. In addition, Black women in both Seattle and Portland are concentrated in healthcare and low skill service occupations and some clerical occupations. Black men were found to be concentrated in low skill laborer and some operative occupations. 
However, Black women in Seattle were far more concentrated in clerical occupations in comparison to their counter parts to the south. In Portland, Black men were slightly better represented in the skilled crafts. Also, Black women in Seattle were a little better represented in professional, specialty and managerial occupations. Generally, these findings are very similar to those found by Gibson et al in Pittsburgh and Detroit.

\section{Black men in Skilled Crafts, Laborer and Operative Occupations (Table 1)}

Table 1 reveals that the six skilled craft occupations selected for analysis were male gender typed. In Seattle, Black men were underrepresented in all six and in Portland Black men were underrepresented as carpenters, plumbers, machinists and boilermakers (see Table 1). The exceptions were electricians and auto mechanics, where Black men were evenly represented. Amongst the ten operative and laborer occupations analyzed, Black men in Seattle were overrepresented in seven with exception of printing press operators (even representation), assemblers (underrepresented) and machine operators (underrepresented). A similar pattern was found amongst Black men in Portland who were also overrepresented in seven of ten laborer and operative occupations. The exceptions were printing press operators, machine operators and truck drivers, where Black men in Portland were underrepresented.

\section{Black Men in Service and Healthcare Occupations (Table 2)}

Occupational patterns were far more varied between the two cities in regard to Black men in service and healthcare professions. With the exception of waiters (even representation) and clinical laboratory technicians (underrepresented) Black men in Seattle were overrepresented in the other ten healthcare and service occupations selected for analysis (see table 2). Like Black men in Seattle, Black men in Portland were found to be overrepresented in four of the five healthcare occupations selected, with the exception of health technologists (underrepresented). 
However, amongst service occupations the pattern changes. Unlike in Seattle, Black men in Portland, with the exception of cooks (even representation), meat cutters (overrepresentation) and janitors (overrepresentation) were found to be underrepresented in three of the six service occupations examined. This result is somewhat surprising because Black men in Seattle are found to be significantly overrepresented as cooks and food preparers and evenly represented as waiters while in Portland Black men were underrepresented as waiters and food prepares and evenly represented as cooks.

\section{Black Men in Professional, Specialty and Managerial Occupations (Table 3)}

Similar patterns of occupational representation were found between the two cities in regards to Black men in top tier white collar professions (see table 3). In both Portland and Seattle, Black men were underrepresented in eleven of the sixteen professional, specialty and managerial occupations analyzed. In Seattle Black men were found to be evenly represented as accountants + auditors and overrepresented as human resource managers, administrators in education, managers of service organizations and financial managers. Similar to Seattle, Black men in Portland were evenly represented as administrators in education, managers of service organization and overrepresented as human resource managers. Also, Black men in Portland were overrepresented as managers in lodging and food serving establishments and lawyers. 


\section{Table 1}

\section{Black Men in Skilled Crafts,}

Operative and Laborer Occupations

Seattle MSA

Black Men in Skilled Crafts, Operative and Laborer Occupations

Underrepresented

Automobile mechanics

Carpenters

Electricians

Plumbers, pipefitters, and steamfitters

Machinists

Boilermakers

Machine operators

Assemblers

Portland MSA

Black Men in Skilled Crafts, Operative and Laborer Occupations

Underrepresented

Carpenters

Plumbers, pipefitters, and steamfitters

Machinists

Boilermakers

Printing press operators

Pressing machine operators

Truck drivers

\section{Even Representation}

Printing press operators

(1)

\section{Overrepresented}

Construction laborers

Laborers, except construction

Punching press machine operators

Pressing machine operators

Truck drivers

Bus drivers

Taxicab drivers and chauffeurs

\section{Overrepresented}

Punching and stamping press machine operators

Machine operators

Assemblers

Bus drivers

Taxicab drivers and chauffeurs

Construction laborers

Laborers, except construction 
Table 2

Black Men in Service and

Healthcare Occupations

Seattle MSA

Black Men in Service and

Healthcare Occupations

\section{Underrepresented}

Clinical laboratory technologists
Even Representation

Cooks

Waiters

Miscellaneous food preparation

Child care workers

Garage and service station

attendants

Note: Occupations in bold are gender typed

Source: 5\% PUMS data - 2000 US Census

See Appendix 2 for index values
Waiters

\section{Even Representation Overrepresented}

Nursing aides and orderlies

Registered nurses

Licensed practical nurses

Health technologists

Cooks

Miscellaneous food

preparation occupations

Janitors and cleaners

Child care workers

Butchers and meat cutters

Garage and service station attendants

\section{Overrepresented}

Registered nurses Clinical laboratory technologists

Licensed practical nurses

Nursing aides and orderlies

Butchers and meat cutters

Janitors 


\section{Table 3}

\section{Black Men in Professional, Specialty}

\section{And Managerial Occupations}

\section{Seattle MSA}

Black Men in Professional, Specialty and Managerial Occupations

\section{Underrepresented}

Chief executives public administration

Managers, marketing, advertising,

and public relations

Managers, medicine and health

Managers, food serving and

lodging establishments

Managers, properties and real estate

Managers and administrators

Funeral directors

Architects

Lawyers

Physicians

Computer programmer

\section{Portland MSA}

Black Men in Professional, Specialty and Managerial Occupations

\section{Underrepresented}

Chief executives and general

administrators, public administration

Financial managers

Managers, marketing, advertising,

and public relations

Managers and administrators

Accountants and auditors

Architects

Physicians

Real estate managers

Managers and administrators

Managers in medicine and health Computer programmer

Note: Occupations in bold are gender typed

Source: 5\% PUMS data - 2000 US Census

\section{Even Representation}

Accountants and auditors

\section{Overrepresented}

Financial managers

Managers, human resources +labor

Administrators in education

Managers, service organizations

\section{Even Representation}

Administrators in education

Managers, service organizations.

\section{Overrepresented}

Managers, human resources + labor Managers, food serving and lodging establishments

Lawyers

See Appendix 2 for index values 


\section{Table 4}

\section{Black Women in Clerical Occupations}

Seattle MSA

Black Women in Clerical Occupations

Underrepresented

Secretaries

Portland MSA

Black Women in Clerical Occupations

Underrepresented

Secretaries

Typists

Receptionists

File clerks

Bank tellers

\section{Even Representation}

Overrepresented

Computer operators

Typists

Receptionists

File clerks

General office clerks

Bank tellers

Data-entry keyers

\section{Even Representation}

\section{Overrepresented}

Computer operators

General office clerks

Data-entry keyers

Note: Occupations in bold are gender typed

Source: 5\% PUMS data - 2000 US Census

See Appendix 2 for index values

\section{Black Women in Clerical Occupations (Table 4)}

Amongst the clerical occupations, which are for the most part are female gender-typed, a significant contrast was found between Black women in Seattle and Portland. In Seattle, Black 
women were extremely overrepresented in the clerical occupations with exception of secretaries, where Black women in both cities were underrepresented (see table 4). However, in Portland a very different pattern emerges. Black women in Portland were found to be underrepresented in five of the eight clerical occupational examined and overrepresented in three. In addition, Black women in Portland seem to be completely absent from clerical occupations which require direct interaction with public such as secretaries, receptionists and bank tellers (similar to Black waiters in Portland). And, while clerical workers are generally paid relatively modest wages, clerical work does not often require a four year college degree and provides women with limited education attainment the opportunity to be a part of the lower middle-class or working poor. Without even this limited economic foothold, Black women in Portland face an extremely limited opportunity structure.

\section{Black Women in Sales, Service and Healthcare Occupations}

Amongst the five healthcare occupations examined, Black women in Seattle were found to be overrepresented in four, with exception of registered nurses. In both Portland and Seattle, Black women were found to be extremely overrepresented (more than $200 \%$ of the crowding index value) as nurses' aides and licensed nurses. In Portland, Black women were evenly represented as registered nurses and health technologists and underrepresented as clinical laboratory technicians. Amongst the sales occupations analyzed, Black women in Seattle were evenly represented as sales persons but were significantly underrepresented as supervisors and proprietors in sales. In Portland, Black women were underrepresented as both sales persons and supervisors and proprietors in sales. Amongst service occupation, Black women in both cities were overrepresented as janitors, childcare workers and cashiers and underrepresented as food preparers and service station attendants. In Portland, Black women were evenly represented as 
waitresses but underrepresented in Seattle. In Seattle, Black women were evenly represented as cooks but overrepresented as in Portland.

Table 5

\section{Black Women in Sales}

\section{Service and Healthcare Occupations}

Seattle MSA

Black Women in Service, Sales

and Healthcare Occupations

\section{Underrepresented}

Registered nurses

Waiters and waitresses

Miscellaneous food preparation

Garage and service station attendants

Supervisors and proprietors, sales

\section{Portland MSA}

Black Women in Service, Sales

and Healthcare Occupations

Underrepresented
Clinical laboratory technologists
and technicians
Supervisors and proprietors, sales
Sales Person
Miscellaneous food preparation
Garage and service station attendants

Note: Occupations in bold are gender typed

Source: 5\% PUMS data - 2000 US Census

See Appendix 2 for index values

\author{
Even Representation \\ Cooks \\ Sales Person
}

Even Representation

Registered nurses

Health technologists and technicians

Waiters and waitresses

\section{Overrepresented}

Clinical laboratory technologists

Licensed practical nurses

Health technologists

Nursing aides and orderlies

Child care workers

Janitors and cleaners

Cashiers

\section{Overrepresented}

Licensed practical nurses

Cashiers

Nursing aides and orderlies

Cooks

Janitors and cleaners

Child care workers

Butchers and meat cutters 


\section{Black Women in Professional, Specialty and Managerial Occupations}

Amongst the top tier white collar occupations analyzed Black women in both cities were significantly underrepresented. In Seattle, Black women were underrepresented in ten out of sixteen occupations and in Portland black women were underrepresented in thirteen of sixteen. In both Seattle and Portland, Black women were found to be overrepresented as administrators in education and managers in medicine. In Portland, Black women were overrepresented as managers in marketing and computer programmers. In Seattle, Black women were evenly represented as managers in marketing, physicians and managers in service organizations. Also, Black women in Seattle were overrepresented as managers in real estate.

Table 6

Black Females in Professional

Managerial and Specialty Occupations

Seattle MSA

Black Women in Professional, Specialty and Managerial Occupations

\section{Underrepresented}

Chief executives in public administration

Financial managers

Managers, human resources and labor

Managers, food and lodging

Funeral directors

Managers and administrators

Accountants and auditors

Architects

Lawyers

Computer programmers

Continued on next page

\author{
Even Representation \\ Overrepresented \\ Managers, marketing \\ Administrators in education \\ Managers, service org. \\ Physician \\ Managers, medicine \\ Managers, real estate
}




\section{Portland MSA}

Black Women in Professional, Specialty and Managerial Occupations

Underrepresented

Chief executives in public administration

Financial managers

Human resources and labor

relations managers

Managers, food serving

and lodging establishments

Managers, properties and real estate

Funeral directors

Managers, service organizations

Managers and administrators

Accountants and auditors

Architects

Lawyers

Physicians

Source: 5\% PUMS data - 2000 US Census

See Appendix 2 for index values
Even Representation

Overrepresented

Managers, marketing,

Administrators in education

Managers, medicine

Computer programmers

\section{Comparing Studies: Bergmann's 1960 analysis of Black Males in Blue-Collar Occupations*}

A direct comparison of Bergmann's findings to those found in this report is problematic because the occupational classification systems used are different and because Bergmann limited her study to Black men in blue-collar occupations, while the current study is limited to a subset of 25 blue collar occupations. However, a striking similarity can be found between the types of bluecollar occupations African Americans were crowded into and out of in 1960 and the racial occupational patterns found in this report. In Bergmann’s study, African American males were found to be crowded into laborer and service occupations and excluded from most skilled trade and some operative occupations. This study also finds that Black men continue to face barriers to entry into skilled craft occupations. However, unlike in Bergmann’s analysis, in which African American men were for the most part underrepresented in operative professions, in this study, a 
significant degree of occupational crowding was found within operative professions, particular vehicle drivers. In addition, Black men in Portland were slightly better represented in the skilled trades and crafts than their counterparts in Seattle. Black men in Seattle were underrepresented in all six of the skilled trades occupations analyzed, while in Portland, Black men have been able to find employment both as electricians and auto mechanics.

\section{Comparing Studies: Pittsburgh and Detroit in 1990 vs. Portland and Seattle in 2000}

Comparing Gibson, Darity and Myers's findings in 1990 to the current study is relatively straight forward because the set of occupations analyzed in this study is very similar. They found in 1990, within blue-collar and service employment, black women were underrepresented in both craft and operative occupations and concentrated in low-skill service occupations. Black men were underrepresented in the craft occupations and concentrated in low-skill operative, laborer, and service occupations. Amongst white-collar occupations, both Black men and women in Pittsburgh and Detroit were largely excluded from high-skill private sector managerial occupations. While in Detroit, both Black men and women had made significant in-roads in public sector managerial and administrative positions. This study's results mirror many of the findings from the 1990 study. Black men continue to be crowded out of the highly unionized and well compensated skilled craft occupations and crowded into low-skill operative and laborer occupations, professions that offer limited career mobility and job security. And, like Pittsburgh and Detroit in 1990, Black men and women continue to find themselves crowded out of private sector managerial, professional and specialty occupations in Seattle and Portland. Overall, the level of continuity between the two studies is disturbing. African Americans in Seattle and Portland in 2000 face a similar up-hill climb out of undesirable jobs and into more desirable and better compensated occupations as there 1990 counterparts in Detroit and Pittsburgh. 


\section{Conclusion}

It is clear from the empirical analysis presented that Black men and women in the Pacific Northwest, with a few exceptions, are largely excluded from the most desirable and best compensated professions and crowded into those jobs at the bottom of the occupation ladder. In addition, and despite the limitations of this report, the troubling continuities observed between the results of this analysis and those conducted by Bergmann and Gibson et al, give an indication of the long road ahead for racial equality in the America workforce. In her analysis of occupational crowding in blue collar jobs in 1960, Barbara Bergmann concluded that racial desegregation in occupations would come at a significant economic cost for White men with low-levels of educational attainment. However, the findings of this report make it very clear that the type of workforce redistribution required to achieve balanced occupational representation by race would come at a considerable price to Whites with both high and low levels of educational attainment. 
Technical Notes

Data Set:

5\% Public Use Micro-data Samples (PUMS) from the US Census Bureau contains detailed information regarding household and personal characteristics for individuals based on geographic area. The 2000 PUMS data used in this study will come from the Integrated Public Use Micro-data Series (IPUMS-USA), which consists of more than fifty high-precision samples of the American population drawn from fifteen federal censuses and from the American Community Surveys of 2000-2008. The IPUMS-USA online data base will allow the researcher to extract and analyze a customized data set from 5\%PUMS.

Occupational Variable: OCC1990

Because the Census Bureau has reorganized its occupational classification system in almost every census administered since 1850, the researcher has chosen to use the OCC1990 which provides a consistent long-term classification of occupations. The OCC1990 classification scheme contains 389 categories. The researcher has chosen to analyze 59 occupations representing a broad cross section of jobs in terms of educational requirements, pay and status (see appendix A). 55 of the 59 occupations selected for analysis matched the 59 occupations used for "Revisiting Occupational Crowding in the United States: A Preliminary Study "(Gibson, Darity and Myers. 1998). The researcher believes that the considerable overlap should allow for a substantive comparison between the two studies.

Race Variable: Race

RACE has both a general version (1 digit) and a detailed version (3 digits). For this study the general version of the variable will be used (codebook).

Variable Recoding:

In order to isolate the African American population for study, the researcher will aggregate the other eight RACE responses into one.

Education Variable: EDUC

EDUC represents a respondents educational attainment, as measured by the highest year of school or degree completed (Note that completion differs from the highest year of school attendance). EDUC has both a general version (2 digits) and a detailed version (3 digits). This study will make use of the general version (codebook).

Variable Recoding:

In order to obtain more accurate results for educational attainment in the sample, the researcher will omit cases in which a respondent failed to answer the question (code 00).

Income Variable: INCWAGE 
INCWAGE reports each respondent's total pre-tax wage and salary income for the previous year (Codebook). Sources of income in INCWAGE include wages, salaries, commissions, cash bonuses, tips, and other money income received from an employer. Payments-in-kind or reimbursements for business expenses are not included.

Variable Recoding:

In order to obtain more accurate INCWAGE results, the researcher will either omit cases in which a respondent failed to answer the question (code 999999).

Geographic Variable: METAREA

Metropolitan areas are counties or combinations of counties centering on a substantial urban area. METAREA has both a general version (3 digits) and a detailed version (4 digits). For this study, the general version will be used (codebook).

Portland-Vancouver-Hillsboro, OR-WA

The Portland-Vancouver-Hillsboro, OR-WA Metropolitan Statistical Area (MSA), also known as the Portland metropolitan area or Greater Portland, is an urban area in the U.S. states of Oregon and Washington centered around the city of Portland, Oregon. The U.S. Census Bureau's definition for the MSA is currently all of the following counties: Clackamas County, Oregon; Columbia County, Oregon; Multnomah County, Oregon; Washington County, Oregon; Yamhill County, Oregon; Clark County, Washington; and Skamania County, Washington. ${ }^{[1]}$ The Washington counties are separated from Oregon by the Columbia River.

Seattle-Tacoma-Bellevue, WA

The Seattle-Tacoma-Bellevue, WA MSA includes the city of Seattle, King County, Snohomish County, and Pierce County within the Puget Sound region.

AGE:

AGE reports the person's age in years (3 digits) as of the last birthday.

Variable Recoding:

In order to isolate the working-age population for study, the researcher will omit individuals in the sample below the age of 25 and over the age of 65 .

Gender Variable: SEX

SEX reports whether the person was male (1) or female (2).

PERWT (Person Weight):

PERWT indicates how many persons in the U.S. population are represented by a given person in the IPUMS sample. 


\section{References:}

Beggs, John J.. 1995. The institutional environment: “Implications for race and gender inequality in the U.S.labor market”. American Sociological Review. 60 (1). 612-33.

Beggs, John J. Villemez, Wayne J. and Arnold, Ruth. 1997. "Black Population Concentration and Black-White Inequality: Expanding the Consideration of Place and Space Effects". Social Forces. 76(1): 65-91.

Bergmann, Barbara R. 1971. "The Effect on White Incomes of Discrimination in Employment.” Journal of Political Economy 79(2): 294-313.

Browne, Irene. 1997. “Explaining the Black-White Gap in Labor Force Participation among Women Heading Households”. American Sociological Review 62(2): 236-52

Burr, Jefferey A. Galle, Omer R. and Fosset, Mark A.. "Racial Occupation Inequality in Southern Metropolitan Areas, 1940-1980: Revisiting the Visibility-Discrimination Hypothesis”. Social Forces. 69(1). 831-50

Cohen, Phillip N.. 1998. "Black Concentration Effects on Black White Gender Inequality: Multi Level Analysis for U.S. Metropolitan Areas”. Social Forces. 77(1). 207-29.

Cohen, Phillip N. 2001. Race, Class and Labor Markets: the White Working Class and Racial Composition of U.S. Metropolitan Areas. Social Science Research. 30(1). 146-69.

Petit, Becky and Ewert, Stephanie. 2009. Employment Gains and Wage Declines: The Erosion of Black Women’s Relative Wages Since 1980”. Demography. 46 (3) 469-92.

Tomaskovic-Devey, Donald. Zimmer, Catherine. Stainback, Kevin. Robinson, Corre. Taylor, Tiffany and McTagu, Tricia. 2006. ”Documenting Desegregation: Segregation in American Workplaces by Race, Ethnicity, and Sex, 1966-2003”. American Sociological Review. 71 (4) 565-88.

Fairlie, Robert W. and Sundstrom, William A.. 1997. “The Racial Unemployment Gap in LongRun Perspective.” American Economics Association Papers and Proceedings. 87(2): 306-10.

Dozier, Raine. “Accumulating Disadvantage: The Growth in the Black-White Wage Gap Among Women” Unpublished Dissertation. Western Washington University.

Digest of City Club Report, The Negro in Portland - July, 1945," Portion of Portland City Club Report, 1945. Folder 3, Box 3, Gov. Snell Records, OSA.

Fossett, Mark A., , Galle R. Omer , and Kelly R.William. 1986. "Racial Occupational Inequality, 1940-1980: National and Regional Trends." American Sociological Review 51 (3). 421-29.

Fosset, Mark and Swicegood, Gray. 1982. "Rediscovering City Differences in Occupational Inequality”. American Sociological Review. 47(5). 661-89. 
Gibson, Karen, Darity, William Jr. and Myers, Samuel Jr. "Revisiting Occupational Crowding in the United States: A Preliminary Study”. Feminist Economics. 4 (3) 73-95.

Huffman, Matt L. and Cohen, Philip N.. 2002. “Occupational Segregation and the Devaluation of Women's Work Across US Labor Markets”. Social Forces. 81(3). 881-907

Huffman, Matt L. and Cohen, Philip N.. 2003. “Individuals, Jobs, and Labor Markets: The Devaluation of Women's Work”. American Sociological Review. 68(3). 443-63.

Huffman, Matt L. and Cohen, Philip N. 2004. "Racial Wage Inequality: Job Segregation and Devaluation across U.S. Labor Markets” American Journal of Sociology. 109 (4). 902-36.

Huffman, Matt L. and Cohen, Philip N.. 2007. "Black Under-representation in Management across U.S. Labor Markets". The Annals of the American Academy of Political and Social Science. 609 (1). 181-199.

Holzer, Harry J. Offner, Paul and Sorensen, Elaine. 2004. “Declining Employment among Young Black Less-Educated Men: The Role of Incarceration and Child Support”. Journal of Policy Analysis and Management. 24 (2), 329-71.

Kim, Marlene. 2002. "Has the Race Penalty for Black Women Disappeared in the United States”. Feminist Economics. 8(2). 115-24.

King, Mary. (1992). “Occupational segregation by race and sex, 1940-88.” The Monthly Labor Review. 115(4) 30-8.

Muame, David J. Jr. 1999. “Glass Ceilings and Glass Escalators”. Occupational Segregation and Race and Sex Differences in Managerial Promotion. Work and Occupations. 26(1). 483-509.

McTague, Tricia. Stainback, Kevin, and Tomaskovic-Devey. Donald. 2009."An Organizational Approach to Understanding Sex and Race Segregation in U.S. Workplaces.". Social Forces 87(3). $1499-1527$

Steinbeck, Kevin and Tomaskovic-Devey, Donald D. (2007). "Discrimination and Desegregation: Equal Opportunity Progress in U.S. Private Sector Workplaces since the Civil Rights Act". The Annals of the American Academy of Political and Social Science. 609 (1). 49-84.

Taylor, Quintard.“The Great Migration: The Afro-American Communities of Seattle and Portland during the 1940's”.Arizona and the West. 23(2). 109-26 
Appendix 1 - Courtesy of Prof. Karen Gibson, Portland State University

Per Capita Income and Black-White Ratios, 1960-2006 (in 2006 dollars)

\begin{tabular}{|r|r|r|r|r|r|r|r|r|r|}
\hline & \multicolumn{3}{|c|}{ Portland } & \multicolumn{3}{|c|}{ Seattle } & \multicolumn{3}{c|}{ United States } \\
\cline { 2 - 11 } & White & Black & B/W & White & Black & B/W & White & Black & B/W \\
\hline $\mathbf{1 9 6 0}$ & 21,102 & 15,782 & $\mathbf{0 . 7 5}$ & 20,643 & 14,763 & $\mathbf{0 . 7 2}$ & 20,571 & 10,218 & $\mathbf{0 . 5 0}$ \\
\hline $\mathbf{1 9 7 0}$ & 18,661 & 17,266 & $\mathbf{0 . 9 3}$ & 27,255 & 20,793 & $\mathbf{0 . 7 6}$ & 32,615 & 24,510 & $\mathbf{0 . 7 5}$ \\
\hline $\mathbf{1 9 8 0}$ & 20,883 & 12,440 & $\mathbf{0 . 6 0}$ & 24,516 & 14,535 & $\mathbf{0 . 5 9}$ & 18,737 & 11,817 & $\mathbf{0 . 6 3}$ \\
\hline $\mathbf{1 9 9 0}$ & 23,961 & 12,461 & $\mathbf{0 . 5 2}$ & 31,860 & 16,208 & $\mathbf{0 . 5 1}$ & 24,208 & 13,671 & $\mathbf{0 . 5 6}$ \\
\hline $\mathbf{2 0 0 0}$ & 29,785 & 16,475 & $\mathbf{0 . 5 5}$ & 42,260 & 21,461 & $\mathbf{0 . 5 1}$ & 29,062 & 16,905 & $\mathbf{0 . 5 8}$ \\
\hline $\mathbf{2 0 0 6}$ & 31,647 & 13,126 & $\mathbf{0 . 4 1}$ & 46,066 & 18,349 & $\mathbf{0 . 4 0}$ & 29,406 & 16,559 & $\mathbf{0 . 5 6}$ \\
\hline \multicolumn{10}{|c|}{} \\
\hline
\end{tabular}

Unemployment Rates \& Black-White Ratios: Portland, Seattle, and United States, 1970-2006

\begin{tabular}{|c|c|c|c|c|c|c|c|c|c|}
\hline & \multicolumn{3}{|c|}{ Portland } & \multicolumn{3}{|c|}{ Seattle } & \multicolumn{3}{|c|}{ United States } \\
\hline & & & B/W & & & $\mathbf{B} / \mathbf{W}$ & & & B/W \\
\hline Males & White & Black & Ratio & White & Black & Ratio & White & Black & Ratio \\
\hline 1970 & $7.4 \%$ & $11.9 \%$ & 1.6 & $8.5 \%$ & $13.1 \%$ & 1.5 & $3.6 \%$ & $6.3 \%$ & 1.8 \\
\hline 1980 & $6.2 \%$ & $15.2 \%$ & 2.5 & $5.9 \%$ & $11.9 \%$ & 2.0 & $5.9 \%$ & $12.3 \%$ & 2.1 \\
\hline 1990 & $5.9 \%$ & $15.0 \%$ & 2.5 & $4.3 \%$ & $13.9 \%$ & 3.2 & $5.3 \%$ & $13.7 \%$ & 2.6 \\
\hline 2000 & $6.6 \%$ & $15.6 \%$ & 2.4 & $4.5 \%$ & $11.1 \%$ & 2.5 & $4.4 \%$ & $12.3 \%$ & 2.8 \\
\hline 2006 & $6.2 \%$ & $16.6 \%$ & 2.7 & $4.1 \%$ & $14.9 \%$ & 3.6 & $5.0 \%$ & $13.4 \%$ & 2.7 \\
\hline \multicolumn{10}{|l|}{ Females } \\
\hline 1970 & $5.4 \%$ & $8.1 \%$ & 1.5 & $7.3 \%$ & $10.4 \%$ & 1.4 & $4.8 \%$ & $7.7 \%$ & 1.6 \\
\hline 1980 & $5.1 \%$ & $13.4 \%$ & 2.6 & $4.6 \%$ & $9.6 \%$ & 2.1 & $5.7 \%$ & $11.3 \%$ & 2.0 \\
\hline 1990 & $5.2 \%$ & $10.6 \%$ & 2.1 & $3.5 \%$ & $10.7 \%$ & 3.1 & $5.0 \%$ & $12.2 \%$ & 2.4 \\
\hline 2000 & $4.9 \%$ & $11.5 \%$ & 2.4 & $3.7 \%$ & $8.9 \%$ & 2.4 & $4.3 \%$ & $10.9 \%$ & 2.6 \\
\hline 2006 & $4.8 \%$ & $10.4 \%$ & 2.2 & $4.4 \%$ & $12.1 \%$ & 2.8 & $5.1 \%$ & $11.9 \%$ & 2.3 \\
\hline \multicolumn{10}{|c|}{ Source: U.S. Census \& 2006 ACS } \\
\hline \multicolumn{10}{|c|}{ *2000 \& 2006 for Non-Hispanic Whites } \\
\hline
\end{tabular}

Percent with Incomes below Poverty, 1970-2006

\begin{tabular}{|c|c|c|c|c|c|c|}
\hline & \multicolumn{2}{|c|}{ Portland } & \multicolumn{2}{c|}{ Seattle } & \multicolumn{2}{c|}{ United States } \\
\hline & White & Black & White & Black & White & Black \\
\hline $\mathbf{1 9 7 0}$ & 17 & 30 & 14 & 24 & 14 & 28 \\
\hline $\mathbf{1 9 8 0}$ & 11 & 29 & 9 & 23 & 9 & 29 \\
\hline $\mathbf{1 9 9 0}$ & 12 & 31 & 9 & 25 & 10 & 25 \\
\hline $\mathbf{2 0 0 0}$ & 11 & 26 & 8 & 23 & 8 & 25 \\
\hline $\mathbf{2 0 0 6}$ & 13 & 41 & 9 & 35 & 9 & \\
\hline
\end{tabular}


Appendix 2

Black Men Seattle

Healthcare and Service Occupations

Nursing aides, orderlies, and attendants

Registered nurses

Clinical laboratory technologists and technicians

Licensed practical nurses

Health technologists and technicians, n.e.c.

Waiters and waitresses

Cooks

Miscellaneous food preparation occupations

Janitors and cleaners

Child care workers, n.e.c.

Butchers and meat cutters

Skilled Crafts, Operative and Laborer Occupations

Automobile mechanics

Carpenters

Electricians

Plumbers, pipefitters, and steamfitters

Machinists

Boilermakers*

Construction laborers

Garage and service station related occupations*

Laborers, except construction

Punching and stamping press machine operators

Printing press operators
Male Female \%Black index Exp.

Black\%

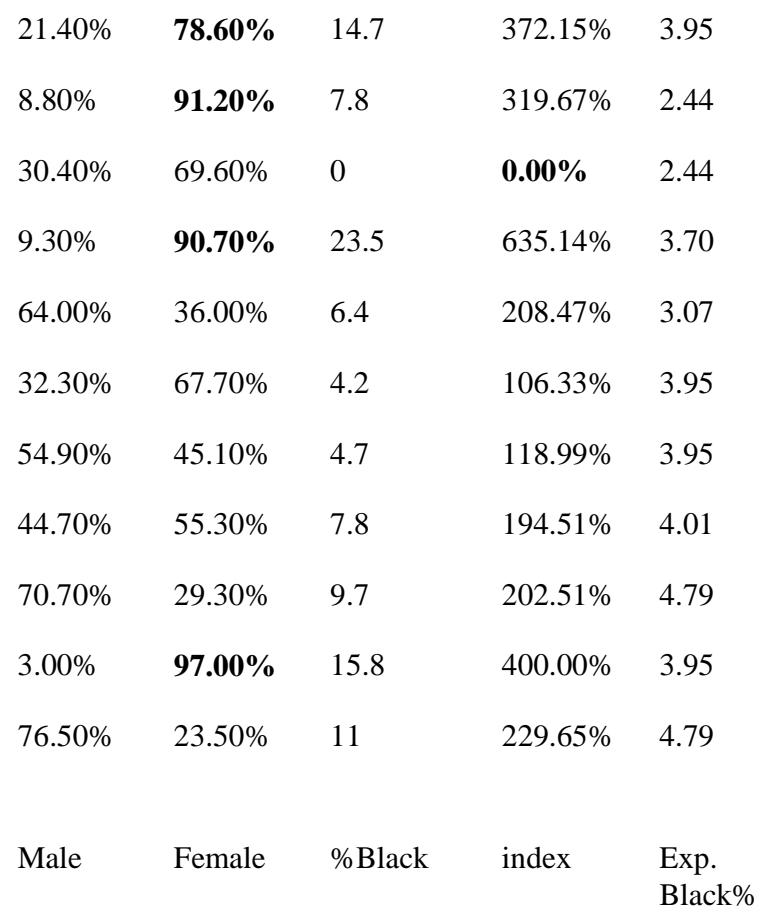

\begin{tabular}{|lllll}
$\mathbf{9 7 . 6 0} \%$ & $2.40 \%$ & 2.8 & $\mathbf{5 8 . 4 6 \%}$ & 4.79 \\
$\mathbf{9 7 . 5 0} \%$ & $2.50 \%$ & 2.2 & $\mathbf{4 5 . 9 3 \%}$ & 4.79 \\
$\mathbf{9 4 . 5 0} \%$ & $5.50 \%$ & 3.5 & $\mathbf{7 3 . 0 7 \%}$ & 4.79 \\
$\mathbf{9 4 . 8 0} \%$ & $5.20 \%$ & 3.5 & $\mathbf{7 3 . 0 7 \%}$ & 4.79 \\
$\mathbf{9 5 . 3 0} \%$ & $4.70 \%$ & 3.9 & $\mathbf{8 1 . 4 2} \%$ & 4.79 \\
$\mathbf{1 0 0 . 0 0 \%}$ & $0.00 \%$ & 0 & $\mathbf{0 . 0 0 \%}$ & 3.95 \\
$\mathbf{9 1 . 0 0 \%}$ & $9.00 \%$ & 7.5 & $156.58 \%$ & 4.79 \\
\hline $\mathbf{5 1 . 3 0} \%$ & $48.70 \%$ & 10.3 & $260.76 \%$ & 3.95 \\
\hline $\mathbf{8 0 . 5 0} \%$ & $19.50 \%$ & 9.7 & $202.51 \%$ & 4.79 \\
$\mathbf{8 5 . 8 0} \%$ & $14.20 \%$ & 13.4 & $283.30 \%$ & 4.73 \\
\hline $\mathbf{8 4 . 7 0} \%$ & $15.30 \%$ & 5.2 & $108.56 \%$ & 4.79
\end{tabular}


Pressing machine operators

Machine operators, n.s.

Assemblers

Truck drivers

Bus drivers

Taxicab drivers and chauffeurs*

Professional, Managerial and Specialty Occupations

Chief executives and general administrators, public administration

Financial managers

Human resources and labor relations managers

Managers, marketing, advertising, and public relations

Administrators, education and related fields

Managers, medicine and health

Managers, food serving and lodging establishments

Managers, properties and real estate

Funeral directors

Managers, service organizations, n.e.c.

Managers and administrators, n.e.c.

Accountants and auditors

Architects

Lawyers

Physicians

Black Men Portland

\section{Healthcare and Service Occupations}

Registered nurses

Clinical laboratory technologists and technicians

$\begin{array}{lllll}37.60 \% & 62.40 \% & 11.5 & 240.08 \% & 4.79 \\ 67.60 \% & 32.40 \% & 3.4 & \mathbf{7 0 . 9 8 \%} & 4.79 \\ 52.60 \% & 47.40 \% & 2.2 & \mathbf{4 5 . 9 3 \%} & 4.79 \\ \mathbf{9 0 . 0 0 \%} & 10.00 \% & 5.8 & 121.09 \% & 4.79 \\ 57.30 \% & 42.70 \% & 14.3 & 362.03 \% & 3.95 \\ \mathbf{8 4 . 5 0 \%} & 15.50 \% & 15.8 & 400.00 \% & 3.95\end{array}$

Male Female \%Black index Exp. Black\%

\begin{tabular}{lllll}
$\mathbf{8 0 . 4 0} \%$ & $19.60 \%$ & 1.2 & $\mathbf{3 9 . 0 9 \%}$ & 3.07 \\
& & & & \\
$44.20 \%$ & $55.80 \%$ & 3.7 & $120.52 \%$ & 3.07 \\
$41.70 \%$ & $58.30 \%$ & 3.7 & $120.52 \%$ & 3.07 \\
$50.40 \%$ & $49.60 \%$ & 2 & $\mathbf{8 3 . 3 3 \%}$ & 2.40 \\
\hline $35.80 \%$ & $64.20 \%$ & 5.2 & $230.09 \%$ & 2.26 \\
\hline $31.10 \%$ & $68.90 \%$ & 1.6 & $\mathbf{6 6 . 6 7 \%}$ & 2.40 \\
\hline $48.00 \%$ & $52.00 \%$ & 0.5 & $\mathbf{1 2 . 6 6 \%}$ & 3.95 \\
\hline $51.70 \%$ & $48.30 \%$ & 2.9 & $\mathbf{7 3 . 4 2} \%$ & 3.95 \\
\hline $\mathbf{1 0 0 . 0 0 \%}$ & $0.00 \%$ & 0 & $\mathbf{0 . 0 0 \%}$ & 4.79 \\
\hline $34.10 \%$ & $65.90 \%$ & 8.8 & $366.67 \%$ & 2.40 \\
\hline $71.70 \%$ & $28.30 \%$ & 2.4 & $\mathbf{7 2 . 9 5 \%}$ & 3.29 \\
\hline $40.10 \%$ & $59.90 \%$ & 2.6 & $106.56 \%$ & 2.44 \\
\hline $71.00 \%$ & $29.00 \%$ & 0 & $\mathbf{0 . 0 0 \%}$ & 2.26 \\
\hline $63.90 \%$ & $36.10 \%$ & 2 & $\mathbf{8 6 . 5 8 \%}$ & 2.31 \\
\hline $64.00 \%$ & $36.00 \%$ & 1.6 & $\mathbf{6 9 . 2 6 \%}$ & 2.31 \\
\hline
\end{tabular}

Male Female \%Black index Exp. Black\%

$\begin{array}{lllll}9.60 \% & \mathbf{9 0 . 4 0 \%} & 2.1 & 141.89 \% & 1.48 \\ 18.60 \% & \mathbf{8 1 . 4 0 \%} & 21.9 & \begin{array}{l}1479.73 \\ \%\end{array} & 1.48 \\ & & & & \end{array}$


Licensed practical nurses

Health technologists and technicians, n.e.c.

Nursing aides, orderlies, and attendants

Waiters and waitresses

Cooks

Miscellaneous food preparation occupations

Janitors and cleaners

Child care workers, n.e.c.

Butchers and meat cutters

Skilled Crafts, Operative and Laborer Occupations

Automobile mechanics

Carpenters

Electricians

Plumbers, pipefitters, and steamfitters

Machinists

Boilermakers*

Punching and stamping press machine operators

Printing press operators

Pressing machine operators

Machine operators, n.s.

Assemblers

Truck drivers

Bus drivers

Taxicab drivers and chauffeurs*

Construction laborers

Garage and service station related occupations*

Laborers, except construction

Professional, Specialty and Managerial Occupations

\begin{tabular}{lllll}
$12.50 \%$ & $\mathbf{8 7 . 5 0} \%$ & 23.8 & $871.79 \%$ & 2.73 \\
$59.90 \%$ & $40.10 \%$ & 0 & $\mathbf{0 . 0 0 \%}$ & 2.01 \\
$17.60 \%$ & $\mathbf{8 2 . 4 0 \%}$ & 6.4 & $234.43 \%$ & 2.73 \\
\hline $28.20 \%$ & $71.80 \%$ & 1.6 & $\mathbf{5 8 . 6 1 \%}$ & 2.73 \\
\hline $51.50 \%$ & $48.50 \%$ & 4.7 & $172.16 \%$ & 2.73 \\
\hline $42.40 \%$ & $57.60 \%$ & 2.6 & $77.38 \%$ & 3.36 \\
\hline $69.60 \%$ & $30.40 \%$ & 5.1 & $164.52 \%$ & 3.1 \\
\hline $5.40 \%$ & $\mathbf{9 4 . 6 0 \%}$ & 0 & $\mathbf{0 . 0 0 \%}$ & 2.73 \\
\hline $\mathbf{8 3 . 6 0} \%$ & $16.40 \%$ & 3.7 & $119.35 \%$ & 3.1 \\
\hline
\end{tabular}

Male Female \%Black index Exp. Black\%

\begin{tabular}{|c|c|c|c|c|}
\hline $95.70 \%$ & $4.30 \%$ & 3.3 & $106.45 \%$ & 3.1 \\
\hline $96.60 \%$ & $3.40 \%$ & 1 & $36.63 \%$ & 2.73 \\
\hline $98.20 \%$ & $1.80 \%$ & 2.8 & $90.32 \%$ & 3.1 \\
\hline $97.40 \%$ & $2.60 \%$ & 0.5 & $16.13 \%$ & 3.1 \\
\hline $96.90 \%$ & $3.10 \%$ & 1.3 & $41.94 \%$ & 3.1 \\
\hline $100.00 \%$ & $0.00 \%$ & 0 & $0.00 \%$ & 3.28 \\
\hline $85.10 \%$ & $14.90 \%$ & 3.7 & $112.80 \%$ & 3.28 \\
\hline $60.80 \%$ & $39.20 \%$ & 0 & $0.00 \%$ & 3.28 \\
\hline $12.90 \%$ & $87.10 \%$ & 0 & $0.00 \%$ & 3.28 \\
\hline $66.20 \%$ & $33.80 \%$ & 5.2 & $167.74 \%$ & 3.1 \\
\hline $49.70 \%$ & $50.30 \%$ & 3.6 & $116.13 \%$ & 3.1 \\
\hline $91.30 \%$ & $8.70 \%$ & 1.8 & $54.88 \%$ & 3.28 \\
\hline $49.10 \%$ & $50.90 \%$ & 7.5 & $241.94 \%$ & 3.1 \\
\hline $86.00 \%$ & $14.00 \%$ & 9.4 & $344.32 \%$ & 2.73 \\
\hline $90.70 \%$ & $9.30 \%$ & 3.8 & $122.58 \%$ & 3.1 \\
\hline $84.30 \%$ & $15.70 \%$ & 2.8 & $88.33 \%$ & 3.17 \\
\hline $79.90 \%$ & $20.10 \%$ & 7.3 & $235.48 \%$ & 3.1 \\
\hline
\end{tabular}

Male Female \%Black index Exp. Black\% 
Chief executives and general administrators, public administration

Financial managers

Human resources and labor relations managers

Managers, marketing, advertising, and public relations

Administrators, education and related fields

Managers, medicine and health

Managers, food serving and lodging establishments

Managers, properties and real estate

Funeral directors

Managers, service organizations, n.e.c.

Managers and administrators, n.e.c.

Accountants and auditors

Architects

Physicians

Lawyers

\section{Black Women Seattle}

\section{Healthcare, Sales and Service Occupations}

Registered nurses

Clinical laboratory technologists and technicians

Licensed practical nurses

Health technologists and technicians, n.e.c.

Nursing aides, orderlies, and attendants

Waiters and waitresses

Cooks

Miscellaneous food preparation occupations

Child care workers, n.e.c.

Janitors and cleaners

\begin{tabular}{lllll}
$78.60 \%$ & $21.40 \%$ & 0.4 & $\mathbf{1 9 . 9 0 \%}$ & 2.01 \\
& & & & \\
$45.60 \%$ & $54.40 \%$ & 0 & $\mathbf{0 . 0 0 \%}$ & 2.01 \\
$34.20 \%$ & $65.80 \%$ & 4.4 & $218.91 \%$ & 2.01 \\
$54.00 \%$ & $46.00 \%$ & 1.4 & $\mathbf{6 9 . 6 5 \%}$ & 2.01 \\
$42.70 \%$ & $57.30 \%$ & 1.3 & $90.91 \%$ & 1.43 \\
\hline $29.60 \%$ & $70.40 \%$ & 0 & $\mathbf{0 . 0 0 \%}$ & 2.01 \\
\hline $56.80 \%$ & $43.20 \%$ & 4.2 & $153.85 \%$ & 2.73 \\
\hline $51.40 \%$ & $48.60 \%$ & 2.3 & $\mathbf{8 4 . 2 5 \%}$ & 2.73 \\
\hline $60.10 \%$ & $39.90 \%$ & 0 & $\mathbf{0 . 0 0 \%}$ & 2.73 \\
\hline $32.90 \%$ & $67.10 \%$ & 2.1 & $104.48 \%$ & 2.01 \\
\hline $74.40 \%$ & $25.60 \%$ & 0.8 & $\mathbf{3 1 . 7 5 \%}$ & 2.52 \\
\hline $38.70 \%$ & $61.30 \%$ & 1.8 & $\mathbf{8 9 . 5 5 \%}$ & 2.01 \\
\hline $68.80 \%$ & $31.20 \%$ & 0.7 & $\mathbf{4 8 . 9 5 \%}$ & 1.43 \\
\hline $65.30 \%$ & $34.70 \%$ & 0 & $\mathbf{0 . 0 0 \%}$ & 1 \\
\hline $72.00 \%$ & $28.00 \%$ & 2.4 & $240.00 \%$ & 1 \\
\hline & & & & \\
\hline
\end{tabular}

Male Female \%Black index Exp. Black\%

\begin{tabular}{|c|c|c|c|c|}
\hline $8.80 \%$ & $91.20 \%$ & 2.5 & $86.81 \%$ & 2.8 \\
\hline $30.40 \%$ & $69.60 \%$ & 4.1 & $142.36 \%$ & 2.8 \\
\hline $9.30 \%$ & $90.70 \%$ & 11.2 & $269.88 \%$ & 4.1 \\
\hline $64.00 \%$ & $36.00 \%$ & 5.6 & $153.01 \%$ & 3.6 \\
\hline $21.40 \%$ & $78.60 \%$ & 12.2 & $281.11 \%$ & 43 \\
\hline $32.30 \%$ & $67.70 \%$ & 0.8 & $18.43 \%$ & 4.3 \\
\hline $54.90 \%$ & $45.10 \%$ & 4.5 & $103.69 \%$ & 4.3 \\
\hline $44.70 \%$ & $55.30 \%$ & 3.3 & $75.17 \%$ & 4.3 \\
\hline $3.00 \%$ & $97.00 \%$ & 5.8 & $133.64 \%$ & 4.3 \\
\hline $70.70 \%$ & $29.30 \%$ & 7.9 & $152.51 \%$ & 5. \\
\hline
\end{tabular}


Garage and service station related occupations*
Supervisors and proprietors, sales occupations
Sales Person, n.e.c.
Cashiers

Clerical Occupations

Computer operators

Secretaries

Typists

Receptionists

File clerks

Postal clerks except mail carriers

General office clerks

Bank tellers*

Data-entry keyers

Professional, Specialty and Managerial Occupations

Chief executives and general administrators, public administration

Financial managers

Human resources and labor relations managers

Managers, marketing, advertising, and public relations

Administrators, education and related fields

Managers, medicine and health

Managers, food serving and lodging establishments

Managers, properties and real estate

Funeral directors

Managers, service organizations, n.e.c.

Managers and administrators, n.e.c.

$\begin{array}{lllll}51.30 \% & 48.70 \% & 0 & \mathbf{0 . 0 0 \%} & 4.34 \\ 60.10 \% & 39.90 \% & 1.8 & \mathbf{4 1 . 4 7 \%} & 4.34 \\ 61.40 \% & 38.60 \% & 4.3 & 99.08 \% & 4.34 \\ 23.10 \% & 76.90 \% & 7.4 & 170.51 \% & 4.34\end{array}$

Male Female \%Black index Exp. Black\%

$\begin{array}{lllll}49.40 \% & 50.60 \% & 6.1 & 140.55 \% & 4.34 \\ 5.40 \% & \mathbf{9 4 . 6 0 \%} & 3.8 & \mathbf{8 7 . 5 6 \%} & 4.34 \\ 18.00 \% & \mathbf{8 2 . 0 0 \%} & 5.5 & 126.73 \% & 4.34 \\ 5.40 \% & \mathbf{9 3 . 6 0 \%} & 6.2 & 142.86 \% & 4.34 \\ 17.80 \% & \mathbf{8 2 . 2 0 \%} & 6.8 & 156.68 \% & 4.34 \\ 52.50 \% & 47.50 \% & 2.9 & \mathbf{6 6 . 8 2} \% & 4.34 \\ 13.20 \% & \mathbf{8 6 . 8 0} \% & 5.5 & 126.73 \% & 4.34 \\ 15.80 \% & \mathbf{8 4 . 2 0 \%} & 5 & 115.21 \% & 4.34 \\ 18.70 \% & \mathbf{8 1 . 3 0 \%} & 6.5 & 149.77 \% & 4.34\end{array}$

Male Female \%Black index Exp. Black\%

\begin{tabular}{lllll}
$80.40 \%$ & $19.60 \%$ & 1.7 & $\mathbf{4 6 . 4 5 \%}$ & 3.66 \\
& & & & \\
$44.20 \%$ & $55.80 \%$ & 2.6 & $\mathbf{7 1 . 0 4 \%}$ & 3.66 \\
$41.70 \%$ & $58.30 \%$ & 3.1 & $\mathbf{8 4 . 7 0 \%}$ & 3.66 \\
$50.40 \%$ & $49.60 \%$ & 2.8 & $98.25 \%$ & 2.85 \\
$35.80 \%$ & $64.20 \%$ & 4.9 & $194.44 \%$ & 2.52 \\
$31.10 \%$ & $68.90 \%$ & 4.8 & $168.42 \%$ & 2.85 \\
\hline $48.00 \%$ & $52.00 \%$ & 3.3 & $\mathbf{7 6 . 0 4 \%}$ & 4.34 \\
\hline $51.70 \%$ & $48.30 \%$ & 6.2 & $142.86 \%$ & 4.34 \\
$100.00 \%$ & $0.00 \%$ & 0 & $\mathbf{0 . 0 0 \%}$ & 5.18 \\
\hline $34.10 \%$ & $65.90 \%$ & 2.6 & $91.23 \%$ & 2.85 \\
\hline $71.70 \%$ & $28.30 \%$ & 2.5 & $\mathbf{6 5 . 1 0 \%}$ & 3.84
\end{tabular}


Accountants and auditors

Architects

Physicians

Lawyers

Computer programmers

Black Women in Portland

Healthcare Sales and Service Occupations

Registered nurses

Clinical laboratory technologists and technicians

Licensed practical nurses

Health technologists and technicians, n.e.c.

Supervisors and proprietors, sales occupations

Sales Person, n.e.c.

Cashiers

Nursing aides, orderlies, and attendants

Waiters and waitresses

Cooks

Miscellaneous food preparation occupations

Janitors and cleaners

Child care workers, n.e.c.

Butchers and meat cutters

\section{Clerical Occupations}

Computer operators

Secretaries

Typists

Receptionists

$\begin{array}{lllll}40.10 \% & 59.90 \% & 2 & \mathbf{6 9 . 4 4 \%} & 2.88 \\ 71.00 \% & 29.00 \% & 0 & \mathbf{0 . 0 0 \%} & 2.52 \\ 64.00 \% & 36.00 \% & 2.8 & 102.94 \% & 2.72 \\ 63.90 \% & 36.10 \% & 1.3 & \mathbf{4 7 . 7 9 \%} & 2.72 \\ 76.80 \% & 23.20 \% & 1.7 & \mathbf{6 9 . 6 7 \%} & 2.44\end{array}$

Male Female \%Black index Exp. Black\%

\begin{tabular}{lllll}
$9.60 \%$ & $\mathbf{9 0 . 4 0 \%}$ & 1.5 & $108.70 \%$ & 1.38 \\
$18.60 \%$ & $\mathbf{8 1 . 4 0 \%}$ & 0.7 & $\mathbf{5 0 . 7 2 \%}$ & 1.38 \\
$12.50 \%$ & $\mathbf{8 7 . 5 0 \%}$ & 8.6 & $289.56 \%$ & 2.97 \\
$59.90 \%$ & $40.10 \%$ & 2.1 & $100.96 \%$ & 2.08 \\
$62.70 \%$ & $37.30 \%$ & 1.4 & $\mathbf{5 0 . 9 1 \%}$ & 2.75 \\
\hline $67.60 \%$ & $32.40 \%$ & 1.7 & $\mathbf{6 1 . 8 2} \%$ & 2.75 \\
\hline $21.90 \%$ & $78.10 \%$ & 4.2 & $152.73 \%$ & 2.75 \\
\hline $17.60 \%$ & $\mathbf{8 2 . 4 0 \%}$ & 7.5 & $272.73 \%$ & 2.75 \\
\hline $28.20 \%$ & $71.80 \%$ & 2.5 & $90.91 \%$ & 2.75 \\
\hline $51.50 \%$ & $48.50 \%$ & 3.8 & $138.18 \%$ & 2.75 \\
\hline $42.40 \%$ & $57.60 \%$ & 2.3 & $\mathbf{6 4 . 2 5 \%}$ & 3.58 \\
\hline $69.60 \%$ & $30.40 \%$ & 4.8 & $146.79 \%$ & 3.27 \\
\hline $5.40 \%$ & $\mathbf{9 4 . 6 0 \%}$ & 4.1 & $149.09 \%$ & 2.75 \\
\hline $83.60 \%$ & $16.40 \%$ & 33.6 & $1027.5 \%$ & 3.27 \\
\hline
\end{tabular}

Male Female \%Black index Exp. Black\%

$\begin{array}{lllll}38.70 \% & 61.30 \% & 8.7 & 316.36 \% & 2.75 \\ 2.20 \% & \mathbf{9 7 . 8 0 \%} & 2 & \mathbf{7 2 . 7 3 \%} & 2.75 \\ 1.50 \% & \mathbf{9 8 . 5 0 \%} & 0 & \mathbf{0 . 0 0 \%} & 2.75 \\ 8.00 \% & \mathbf{9 2 . 0 0 \%} & 1.7 & \mathbf{6 1 . 8 2 \%} & 2.75\end{array}$


File clerks

Postal clerks except mail carriers

General office clerks

Bank tellers*

Data-entry keyers

Professional, Specialty and Managerial Occupations

Chief executives and general administrators, public administration

Financial managers

Human resources and labor relations managers

Managers, marketing, advertising, and public relations

Administrators, education and related fields

Managers, medicine and health

Managers, food serving and lodging establishments

Managers, properties and real estate

Funeral directors

Managers, service organizations, n.e.c.

Managers and administrators, n.e.c.

Accountants and auditors

Architects

Lawyers

Physicians

Computer programmers

$\begin{array}{lllll}23.30 \% & 76.70 \% & 1.4 & \mathbf{5 0 . 9 1 \%} & 2.75 \\ 53.50 \% & 46.50 \% & 0 & \mathbf{0 . 0 0 \%} & 2.75 \\ 13.30 \% & \mathbf{8 6 . 7 0 \%} & 3.2 & 116.36 \% & 2.75 \\ 8.90 \% & \mathbf{9 1 . 1 0 \%} & 0 & \mathbf{0 . 0 0 \%} & 2.75 \\ 22.30 \% & 77.70 \% & 3.5 & 127.27 \% & 2.75\end{array}$

Male Female \%Black index Exp. Black\%

\begin{tabular}{|c|c|c|c|c|}
\hline $78.60 \%$ & $21.40 \%$ & 1.6 & $76.92 \%$ & 2.08 \\
\hline $45.60 \%$ & $54.40 \%$ & 0.5 & $24.04 \%$ & 2.08 \\
\hline $34.20 \%$ & $65.80 \%$ & 0 & $0.00 \%$ & 2.08 \\
\hline $54.00 \%$ & $46.00 \%$ & 2.7 & $129.81 \%$ & 2.08 \\
\hline $42.70 \%$ & $57.30 \%$ & 1.8 & $148.76 \%$ & 1.21 \\
\hline $29.60 \%$ & $70.40 \%$ & 3.2 & $153.85 \%$ & 2.08 \\
\hline $56.80 \%$ & $43.20 \%$ & 2 & $72.73 \%$ & 2.75 \\
\hline $51.40 \%$ & $48.60 \%$ & 0.6 & $21.82 \%$ & 2.75 \\
\hline $60.10 \%$ & $39.90 \%$ & 0 & $0.00 \%$ & 2.97 \\
\hline $32.90 \%$ & $67.10 \%$ & 1.5 & $72.12 \%$ & 2.08 \\
\hline $74.40 \%$ & $25.60 \%$ & 1.3 & $49.43 \%$ & 2.63 \\
\hline $38.70 \%$ & $61.30 \%$ & 1 & $48.08 \%$ & 2.08 \\
\hline $68.80 \%$ & $31.20 \%$ & 0 & $0.00 \%$ & 1.21 \\
\hline $72.00 \%$ & $28.00 \%$ & 0 & $0.00 \%$ & 1.31 \\
\hline $65.30 \%$ & $34.70 \%$ & 1 & $76.34 \%$ & 1.31 \\
\hline $75.50 \%$ & $24.50 \%$ & 2.9 & $210.14 \%$ & 1.38 \\
\hline
\end{tabular}

Note:: Between .90 and 1.10 is even representation; less than .90 is underrepresentation; greater than .90 is overrepresentation.

Source: Authors’ calculations from 2000 Census of Population and Housing, Public Use Microdata $5 \%$ Sample 